\title{
EKOINNOWACYJNE POTRZEBY PRZEDSIĘBIORSTW Z SEKTORA MSP A POTENCJAL SIECI EKOINNOWACJI ECOLABNET
}

DOI: $10.33141 /$ po.2020.03.02

\section{Jurand Bień, Waldemar Jędrzejczyk Robert Kucęba}

\section{Wprowadzenie}

W spółczesny świat doszedł już do takiego punktu, w którym poziom cywilizacji zaczyna w coraz większym stopniu zagrażać życiu na Ziemi. Dalszy rozwój gospodarczy, mający na celu zaspokajanie stale rosnących potrzeb ludzi, aby nie doprowadził do zagłady ludzkości, powinien być realizowany zgodnie z koncepcją zrównoważonego rozwoju - z uwzględnieniem wymiarów: ekonomicznego, ekologicznego i społecznego. Branie pod uwagę aspektów ekologicznych w procesach produkcyjnych oraz w tworzeniu nowych, innowacyjnych rozwiązań procesowych i produktowych określa się mianem ekoinnowacji.

Poziom ekoinnowacyjności wszystkich gospodarek świata jest jeszcze niski, przy czym daje się zauważyć duże zróżnicowanie w zależności od regionów świata lub państw, warunkowane stopniem ich rozwoju i uprzemysłowienia, np. poziom ekoinnowacyjności w Polsce na tle państw Unii Europejskiej jest relatywnie niski (EIO, 2013, s. 19). Działania mające na celu zwiększenie ekoinnowacyjności należy podejmować na wszystkich poziomach gospodarowania: 1) makro - z punktu widzenia gospodarki narodowej, wspólnotowej, globalnej, 2) mezo - z punktu widzenia sektora, łańcucha dostaw, systemu serwisowego, systemu produktowego i 3) mikro - z punktu widzenia produktu, usługi, procesu, przedsiębiorstwa. W proces ten powinny angażować się rządy państw, konsorcja i jednostki badawczo-rozwojowe, korporacje i duże przedsiębiorstwa, a także podmioty z sektora MSP, które mają na celu szukanie i tworzenie sposobów zwiększenia poziomu ekoinnowacyjności. Dobrymi przykładami inicjatyw, które stymulują zachowania ekoinnowacyjne w polskich przedsiębiorstwach, są: Polski Ruch Czystszej Produkcji (CP) oraz projekt Ecolabnet pt. Network of Service Providers for Eco-innovations in Manufacturing SMEs (ECOLABNET).

Project Ecolabnet jest cenną inicjatywą $\mathrm{z}$ uwagi na fakt, iż skierowany jest do sektora MSP, czyli tych przedsiębiorstw, dla których bariery wdrażania ekoinnowacji są znacznie większe niż w przypadku przedsiębiorstw dużych i bardzo dużych. Projekt Ecolabnet jest finansowany w znaczącej części (1,8 mln EUR) z Programu Interreg Regionu Morza Bałtyckiego 2014-2020, w ramach priorytetu „Innowacja”. Całkowity budżet projektu wynosi $2,25 \mathrm{mln}$
Przegląd Organizacji, Nr 3(962), 2020, s. 12-18

www.przegladorganizacji.pl ๑) Towarzystwo Naukowe Organizacji i Kierownictwa (TNOiK)
EUR. Realizacja projektu przypada na okres od stycznia 2019 r. do czerwca 2021 r. Podstawowe konsorcjum partnerów realizujących projekt tworzą instytucje naukowe oraz badawczo-rozwojowe $\mathrm{z}$ sześciu krajów nadbałtyckich, takie jak: Design Centre MUOVA (Finlandia) - lider projektu, Centria University of Technology (Finlandia), Kaunas University of Technology (Litwa), Vilnius University (Litwa), University of Tartu (Estonia), Estrotech Ltd (Estonia), Lithuanian Business Confederation, Sustainable Innovation (Szwecja), VIA University College (Dania) oraz Czestochowa University of Technology (Polska), której przedstawicielami są autorzy niniejszego artykułu. Ze strony polskiego partnera - Politechniki Częstochowskiej, interdyscyplinarny zespół realizujący projekt tworzą pracownicy naukowo-dydaktyczni Wydziału Infrastruktury i Środowiska oraz Wydziału Zarządzania. Misją projektu Ecolabnet jest stworzenie sieci współpracy ponadnarodowej (kraje regionu Morza Bałtyckiego) pomiędzy: instytucjami naukowo-badawczymi (ang. RDI - Research and Development Institute), organizacjami pośredniczącymi (ang. IO - Intermediary Organisation) i przedsiębiorstwami z sektora MSP (ang. SME - Small and Medium Enterprises) w zakresie komercjalizacji ekoinnowacyjnych rozwiązań pilotażowych, opracowanych przede wszystkim w jednostkach partnerów projektu. Wymierną wartością utworzonej sieci jest transfer ustrukturalizowanej, specjalistycznej wiedzy, głównie poprzez wykorzystanie potencjału instytucji naukowo-badawczych, które oprócz swoistego know-how posiadają stosowną infrastrukturę, mogącą służyć małym i średnim przedsiębiorstwom na etapie przygotowywania ekoinnowacyjnych rozwiązań. Tworzona sieć to także rozwijanie umiejętności prowadzenia aktywnego dialogu oraz współpracy z małymi i średnimi przedsiębiorstwami. Dlatego też głównymi beneficjentami - odbiorcami tworzonych wartości w projekcie - są europejskie przedsiębiorstwa produkcyjne z sektora MSP (w szczególności z państw regionu Morza Bałtyckiego), a także organizacje pośredniczące pomiędzy jednostkami naukowymi a przedsiębiorstwami ${ }^{1}$.

Celem głównym artykułu jest określenie potrzeb i oczekiwań przedsiębiorstw z sektora MSP w zakresie ekoinnowacji, których znajomość umożliwi budowę „szytego na miarę” repozytorium wiedzy w sieci ekoinnowacji Ecolabnet. 


\section{Jak należy rozumieć ekoinnowacje?}

$\mathrm{E}$ koinnowacje są szczególnym rodzajem innowacji. Określa się je również mianem innowacji ekologicznych lub innowacji zielonych. Cechą charakterystyczną ekoinnowacji jest to, że przyczyniają się w sposób bezpośredni bądź pośredni do poprawy stanu środowiska naturalnego - wpływają na poprawę stosunków przedsiębiorstw ze środowiskiem naturalnym. Ekoinnowacje traktowane są także jako innowacje, które „chronią człowieka przed szkodliwym wpływem cywilizacji, to tzw. wyroby bezpieczne, niewywołujące szkodliwych reakcji podczas ich używania (konsumowania wyrobu), oraz te wyroby i technologie, które minimalizują odpady konsumpcyjne (nie tylko produkcyjne) lub których odpady mogą być całkowicie utylizowane. Innowacjami ekologicznymi będą również te, do produkcji których jako materiały wykorzystywane są odpady produkcyjne czy też konsumpcyjne" (Kaźmierczak-Piwko i in., 2017, s. 97). Ekoinnowacyjność często łączona jest z koncepcją zrównoważonego rozwoju, oznaczającą rozwój umożliwiający realizację potrzeb obecnych pokoleń $\mathrm{w}$ taki sposób, który nie zmniejsza możliwości przyszłych pokoleń w zaspokajaniu swoich potrzeb (WCED, 1987). Koncepcja zrównoważonego rozwoju powinna uwzględniać zarówno wymiar ekonomiczny, ekologiczny, jak i społeczny. Ekoinnowacje należy więc interpretować jako rozwiązania, które będą opłacalne $z$ ekonomicznego punktu widzenia, przyniosą korzyści dla środowiska naturalnego i nie będą powodować kosztów społecznych (Dudek i in., 2019, s. 14). Znajduje to swoje odzwierciedlenie w licznych definicjach tego terminu, np. Komisja Europejska definiuje innowacje ekologiczne jako wszelkie formy działań zmierzające do znacznego i widocznego postępu w kierunku realizacji celów zrównoważonego rozwoju, poprzez ograniczenie negatywnego oddziaływania na środowisko lub osiąganie większej skuteczności i odpowiedzialności w zakresie wykorzystania zasobów (EC, 2006). W Polsce pierwsza holistyczna definicja ekoinnowacji została zaproponowana przez Główny Urząd Statystyczny. W definicji tej pod pojęciem ekoinnowacji rozumie się „innowacje, które przynoszą korzyści dla środowiska $\mathrm{w}$ postaci nowego lub istotnie ulepszonego produktu (wyrób lub usługa), procesu, metody marketingowej lub organizacyjnej, w porównaniu z rozwiązaniami alternatywnymi” (GUS, 2010, s. 48).

Pojęcie ekoinnowacji jest wielowymiarowe. Można analizować je przekrojowo $\mathrm{z}$ uwzględnieniem różnych kryteriów, m.in. takich jak (Łączny i in., 2012):

- zakres w odniesieniu do cyklu życia - ekoinnowacje mogą być wdrażane tylko na wybranych lub wszystkich etapach cyklu życia produktu, procesu, organizacji;

- skala wdrożenia - ekoinnowacja może mieć różny poziom nowości i dotyczyć organizacji, branży, regionu bądź całego świata;

- metoda opracowywania - ekoinnowacje mogą polegać na modyfikacji istniejących rozwiązań, projektowaniu rozwiązań alternatywnych bądź projektowaniu zupełnie nowych rozwiązań.
Zdaniem autorów niniejszego artykułu, istotę ekoinnowacji w sposób najbardziej zupełny wyjaśnia definicja zaproponowana w pracy R. Kempa i P. Pearsona (2007, s. 7), w której przez ekoinnowacje rozumie się „wytwarzanie i zastosowanie nowych wyrobów, usług, procesów, systemów i procedur w celu zaspokojenia potrzeb ludzkich i zapewnienia lepszej jakości życia przy jednoczesnej minimalizacji zużycia zasobów naturalnych oraz emisji zanieczyszczeń do środowiska na jednostkę wyrobu lub usługi w całym cyklu życia w porównaniu z rozwiązaniami alternatywnymi”.

W literaturze przedmiotu wyróżnia się kilka podstawowych typów ekoinnowacji (EIO, 2013; OECD, 2005):

- produktowe - doskonalenie wyrobów i usług. Celem jest minimalizacja materiałochłonności w całym cyklu życia produktu, zarówno w trakcie jego wytwarzania, jak i użytkowania. Sposoby realizacji: tworzenie nowych produktów lub usług, zwiększenie możliwości naprawczych bądź regeneracyjnych istniejących produktów, zwiększenie udziału materiałów, które można recyrkulować;

- procesowe - doskonalenie procesów. Celem jest przede wszystkim minimalizacja materiałochłonności, zmniejszenie ryzyka i generowanie oszczędności. Sposoby realizacji: wdrożenie nowej bądź znacząco udoskonalonej metody produkcji lub dostawy, implementacja nowych technologii, urządzeń i/lub oprogramowania;

- marketingowe - doskonalenie działań marketingowych. Celem jest szukanie sposobów zachęcania klientów do zakupu, użycia lub wdrożenia rozwiązań ekoinnowacyjnych. Sposoby realizacji: wdrożenie nowej metody marketingowej, determinującej znaczące zmiany m.in. w dystrybucji, promocji, strategii cenowej;

- organizacyjne - doskonalenie działań organizacyjnych. Celem jest zwiększenie efektywności funkcjonowania organizacji. Sposoby realizacji: zmiana modelu biznesu, wdrożenie nowej metody organizacyjnej, wdrożenie nowego systemu zarządzania, które uwzględniają aspekty środowiskowe procesów i wyrobów.

Ekoinnowacje obecnie nie są ograniczane tylko do produktowych i procesowych. Ekoinnowacje, zgodnie z Oslo Manual 2018, rozszerzane są do wszelkich procesów biznesowych, np. w: logistyce i dystrybucji, marketingu i sprzedaży, ICT, administracji i zarządzaniu (OECD, 2019).

Inna często spotkana $\mathrm{w}$ literaturze typologia ekoinnowacji dzieli innowacje ekologiczne na (Rennings, 2000):

- technologiczne - udoskonalenie właściwości produktu, procesu lub mechanizmu dostaw w relacji do produktów i mechanizmów dotychczas istniejących,

- organizacyjne - nowe instrumenty zarządzania (np. ekoaudyty, zielone $\mathrm{B}+\mathrm{R})$,

- społeczne-nowe wzorce zrównoważonej konsumpcji,

- instytucjonalne - doskonalenie polityki zrównoważonego rozwoju, nowe sposoby naukowej oceny oddziaływania na środowisko i udziału społeczeństwa w tym obszarze. 


\section{Ekoinnowacyjność w polskiej praktyce gospodarczej - motywatory, korzyści i bariery wdrażania}

D roblematyką ekoinnowacyności w Polsce zajmuje się wiele instytucji. Cyklicznebadania prowadzone są m.in. przez: Główny Urząd Statystyczny, GfK Polonię, Polską Agencję Rozwoju Przedsiębiorczości, Fundację Partnerstwo dla Środowiska oraz Instytut Gallupa.

Z przeprowadzonych badań wynika, że do czynników, które $\mathrm{w}$ największym stopniu motywują polskie przedsiębiorstwa do wdrażania ekoinnowacji, należą (Ryszko, 2014, s. 130):

- chęć poprawy wizerunku przedsiębiorstwa,

- możliwość obniżenia kosztów prowadzonej działalności,

- regulacje prawne ochrony środowiska - obowiązujące i spodziewane,

- naturalna dbałość o środowisko,

- rosnący popyt na rynku zielonych produktów,

Z kolei czynnikami, które najbardziej stymulują rozwój ekoinnowacji, są wymagania prawne oraz spodziewane korzyści. Zaostrzające się przepisy prawne i normy emisyjne wymuszają na przedsiębiorcach wdrażanie nowych rozwiązań proekologicznych (Cichy, Szafraniec, 2015, s. 33).

Wdrażanie rozwiązań ekoinnowacyjnych w przedsiębiorstwach, w szczególności w przedsiębiorstwach przemysłowych, przynosi liczne korzyści. Korzyść podstawowa to zmniejszanie negatywnego wpływu na środowisko naturalne w obszarze zużycia zasobów i energii oraz emisji zanieczyszczeń na różnych etapach lub w całym cyklu życia produktu. Z korzyścią tą mogą być powiązane inne pozytywne efekty, np. korzyści ekonomiczne, w wyniku: ograniczenia zużycia wody, surowców, materiałów lub energii, redukcji emisji zanieczyszczeń do atmosfery, zmniejszenia ilości wytwarzanych odpadów lub ich odzysk, oraz korzyści społeczne, takie jak poprawa zdrowia społeczeństwa czy zwiększenie świadomości ekologicznej (Diabat, Govindan, 2011; Cichy, Szafraniec, 2015, s. 21). Wymienione korzyści można uznać za czynniki, które także motywują organizacje do wdrażania rozwiązań o charakterze ekoinnowcyjnym.

Niestety, występuje również wiele barier. Do podstawowych kategorii barier wprowadzania ekoinnowacji $\mathrm{w}$ organizacjach zalicza się: bariery prawne, bariery ekonomiczne, bariery popytowe, bariery technologiczne, bariery sfery badawczo-rozwojowej, bariery kadrowe oraz bariery współpracy. Szczegółowe objaśnienia wyróżnionych kategorii barier wdrażania ekoinnowacji można znaleźć $\mathrm{w}$ różnych opracowaniach, m.in. Komisji Europejskiej oraz OECD.

Do podstawowych barier podejmowania działalności ekoinnowacyjnej w polskiej praktyce gospodarczej zalicza się (Ryszko, 2014, s. 130-131):

- wysokie koszty wdrożenia ekoinnowacji,

- niepewny zwrot $\mathrm{z}$ inwestycji $\mathrm{w}$ ekoinnowacje lub zbyt długi okres zwrotu,

- brak środków finansowych w przedsiębiorstwie,
- utrudniony dostęp do finansowania zewnętrznego,

- niechęć do podejmowania ryzyka związanego $\mathrm{z}$ wprowadzaniem niesprawdzonych, innowacyjnych technologii.

\section{Sieć ekoinnowacji Ecolabnet}

ieć Ecolabnet to odpowiedź na brak profesjonalnej sieci świadczenia usług doradczych w zakresie rozwoju ekoproduktów dla małych i średnich przedsiębiorstw w regionie Morza Bałtyckiego. Celem sieci Ecolabnet jest zwiększenie dostępu do wiedzy specjalistycznej, nowych produktów i usług oraz wspieranie konkurencyjności po stronie małych i średnich przedsiębiorstw. Ecolabnet zwiększa potencjał komercjalizacji różnorodnych ekoinnowacji pochodzących ze strony instytucji naukowo-badawczych. Oferowane usługi eksperckie oraz realizowane badania rozwojowe w zakresie projektowania i tworzenia prototypów ekoinnowacji dotyczą przede wszystkim: materiałów biokompozytowych, prototypowania produktów w oparciu o druk 3D, projektowania ekoproduktów, projektowania usług ekoinnowacyjnych, analizy cyklu życia, ekobrandingu oraz opracowania modeli biznesowych - implementacji i użytkowania proponowanych rozwiązań ekoinnowacyjnych.

Podstawowe zadania realizowane $\mathrm{w}$ ramach projektu Ecolabnet dotyczą:

1) analizy rynku i konkurencji oraz oceny potencjału innowacyjnego organizacji,

2) przygotowania do realizacji prac badawczo-rozwojowych,

3) poszukiwania rozwiązań o charakterze ekoinnowacyjnym,

4) prac koncepcyjnych w zakresie modelowania ekoinnowacji,

5) projektowania ekoinnowacji,

6) testowania opracowanych ekoinnowacji,

7) przygotowania i uruchomienia produkcji pilotażowych rozwiązań ekoinnowacyjnych,

8) doskonalenia ekoinnowacji oraz poszukiwania nowych rozwiązań ekoinnowacyjnych.

Wymierną wartością sieci Ecolabnet jest opracowanie cyfrowej platformy współpracy, której celem będzie zaspokojenie potrzeb związanych z komunikacją i rozpowszechnianiem wyników realizacji projektu przez wszystkich partnerów oraz współpracujące przedsiębiorstwa, jednostki naukowo-badawcze i organizacje pośredniczące. Wdrożenie platformy skutkować będzie poprawą skuteczności implementacji i komercjalizacji zrównoważonych, proekologicznych ekoinnowacji w sektorze MSP.

\section{Ekoinnowacyjne potrzeby przedsiębiorstw w krajach nadbattyckich} Metoda badawcza oraz opis populacji badawczej

$\mathbf{R}$ ealizacja projektu Ecolabnet podzielona została na pięć etapów, w ramach których wykonywane są cztery zadania badawcze oraz dodatkowe zadanie, które stanowi szeroką akcję rozprzestrzeniania wyników oraz idei 
stojącej za budową sieci współpracy Ecolabnet. Podstawowe zadania badawcze ujmują działania zmierzające do:

1) rozpoznania i ustanowienia sieci jednostek naukowo -badawczych jako dostawców usług ekoinnowacyjnych,

2) opracowania koncepcji współpracy w celu efektywnego wykorzystania potencjału jednostek naukowo -badawczych,

3) wypracowania zasad określających ramy współpracy pomiędzy zasobami jednostek naukowo-badawczych z zasobami małych i średnich przedsiębiorstw,

4) opracowania prototypów określonych produktów jako elementów demonstracyjnych i wzorcowych dla zrównoważonego projektowania i produkcji.

W każdym zadaniu badawczym udział poszczególnych partnerów projektu jest ścisłe określony, by osiągnąć postawione cele. Należy zaznaczyć, że stanowią one rozwiązanie, którego przyczynkiem jest brak profesjonalnej sieci dla świadczenia usług doradczych w zakresie rozwoju ekoproduktów lub ekousług dla małych i średnich przedsiębiorstw w regionie państw Morza Bałtyckiego. Stąd też ustanowienie i zwiększenie dostępu do wiedzy o zastosowaniu nowych ekoinnowacyjnych produktów oraz usług, a także potencjał do komercjalizacji rozwiązań pochodzących ze strony instytucji naukowo-badawczych, jak też wspieranie konkurencyjności po stronie małych i średnich przedsiębiorców są kluczowym elementem opracowywanej strategii współpracy w sieci Ecolabnet. A jej rozwinięcie będzie możliwe między innymi poprzez identyfikację potrzeb ze strony przedsiębiorstw w oparciu, jak założono w projekcie, o aktywnie przeprowadzoną ankietyzację na poziomie samych przedsiębiorców, jak również organizacji pośredniczących.

Badania w ramach projektu Ecolabnet przeprowadzone $\mathrm{w}$ pierwszym etapie realizacji projektu (lipiec-grudzień 2019 r.) dotyczyły: identyfikacji, pomiaru oraz oceny istotności czynników stymulujących i hamujących dyfuzję ekoinnowacji w MSP w partnerskich krajach nadbałtyckich. W szczególności koncentrowały się one na: identyfikacji i klasyfikacji ekoinnowacji tworzonych lub współtworzonych przez małe i średnie przedsiębiorstwa produkcyjne, ocenie ich wiedzy o ekoinnowacjach, kategoryzacji ekoinnowacji, motywatorach, potrzebach w zakresie rozwoju, implementacji, użytkowania oraz barierach identyfikowanych przez badaną grupę podmiotów.

Próbę badawczą stanowiło 298 podmiotów, w tym: z Estonii - 23\% populacji badawczej, Polski - 19\%, Finlandii - 18\%, Litwy - 16\%, Szwecji - 13\% oraz Danii - 11\%. W całej zagregowanej grupie badanych podmiotów mikro- i małe przedsiębiorstwa stanowily $71 \%$ populacji badawczej - odpowiednio 43 oraz 28\%. Badane przedsiębiorstwa reprezentowały 20 działów (branż) przemysłowych. Pierwsze dziesięć najliczniej reprezentowanych działów stanowiło $50 \%$ populacji badawczej, w tym: produkty spożywcze - $11 \%$, maszyny i urządzenia $-8 \%$, wyroby z gumy i tworzyw sztucznych - $6 \%$, ubrania i tkaniny - $6 \%$, komputerowe produkty elektroniczne i optyczne $-4 \%$, papier i wyroby z papieru $-4 \%$, gotowe wyroby metalowe - $4 \%$, urządzenia elektryczne - $4 \%$ oraz napoje - 3\%. Połowa przedsiębiorstw (50\%) badanej populacji identyfikuje swoją podstawową działalność stricte $\mathrm{w}$ korelacji z ekoinnowacjami, przyjmując postawy proaktywne: praca z ekoinnowacjami - 26\%, ekoinnowacje są w pełni zintegrowane ze strategią firmy - 12\%, misja MSP opiera się na ekoinnowacjach - $12 \%$.

Badania dotyczące problematyki czynników/determinant ekoinnowacji w małych i średnich przedsiębiorstwach w krajach objętych projektem Ecolabnet przeprowadzono dwuetapowo. W pierwszej kolejności partnerzy, na podstawie studium literatury (Burger, 2005; Triguero i in., 2013; Bocken i in., 2014; Karaarslan, 2015; Kuceba, 2019a; 2019b; Kuceba, Zawada, 2019) oraz własnych doświadczeń (liczne panele dyskusyjne), opracowali portfel atrybutów przypisanych wyróżnionym czynnikom stymulującym oraz hamującym dyfuzję ekoinnowacji. Wynikiem pierwszego etapu było wygenerowanie kwestionariusza ankiety badawczej, który składał się z 26 pytań, zarówno jakościowych, jak i ilościowych. Następnie przeprowadzono badania ankietowe z pomocą techniki CAWI.

W niniejszym artykule przedstawiono wyniki badań realizacji pierwszego etapu projektu dotyczące diagnozowania potrzeb i oczekiwań małych i średnich przedsiębiorstw w krajach nadbałtyckich - objętych projektem, w kontekście ekoinnowacji. Tym samym wskazano potrzeby, które mogą być wspierane przez otoczenie, $w$ tym sieć Ecolabnet.

\section{Wyniki pierwszego etapu badań empirycznych}

$\mathrm{W}$ procesie badawczym wyodrębniono trzy grupy potrzeb MSP, którym przypisano odpowiednie kategorie ekoinnowacji: biznesowe, projektowe, technologiczne. Na podstawie dyskursu wszystkich partnerów projektu do poszczególnych kategorii przypisano autonomiczne potrzeby, które poddane były selekcji przez badaną populację nadbałtyckich małych i średnich przedsiębiorstw. Poszczególne potrzeby oceniano w trójstopniowej skali: brak potrzeby, możliwa potrzeba, potrzeba konieczna. Wyniki badań przedstawiono w tabeli 1 .

Przeprowadzone badania potwierdzają, że potrzeby małych i średnich przedsiębiorstw nie koncentrują się wyłącznie na kategorii ekoinnowacji technologicznych. W kategorii biznesowej istotną potrzebą badanych nadbałtyckich MSP jest „branding i komunikacja”. W tym przypadku tylko 30\% badanej populacji nie ma takich potrzeb, z kolei $34 \%$ MSP przewiduje takie potrzeby, a 36\% badanych przedsiębiorstw uważa, że obecnie oczekują wsparcia w zakresie brandingu i komunikacji. Istotnym dla przedsiębiorców jest także wsparcie $\mathrm{w}$ pozyskaniu wiedzy o preferencjach klientów, a w szczególności wiedzy o ich skłonności konsumpcji ekoinnowacyjnych produktów czy usług. $\mathrm{Z}$ badań wynika, że $42 \%$ respondentów przewiduje takie potrzeby, a $32 \%$ badanych nadbałtyckich MSP uważa, że wsparcie w tym zakresie jest silnie skorelowane z dyfuzją ich obecnej działalności ekoinnowacyjnej. W literaturze przedmiotu podkreśla się, że w przypadku MSP ich oczekiwania koncentrują się na wsparciu finansowym zwłaszcza ze źródeł zewnętrznych (Burger, 2005; Karaarslan, 2015; Kuceba, 2019a; 2019b). Badane nadbałtyckie małe i średnie przedsiębiorstwa również oczekują wsparcia finansowego w zakresie ekoinnowacji. Dokładnie 38\% respondentów wskazało możliwość tej potrzeby, a $31 \%$, że jest to aktualna istotna potrzeba wsparcia ich aktywności we wdrażaniu działań ekoinnowacyjnych. Przy czym należy podkreślić, że wsparcie finansowe nie 
Tabela 1. Ekoinnowacyjne potrzeby biznesowe, projektowe i technologiczne nadbattyckich przedsiębiorstw sektora MSP

\begin{tabular}{|c|c|c|c|c|}
\hline Kategorie potrzeb & Ekoinnowacyjne potrzeby przedsiębiorstw & Brak potrzeby & $\begin{array}{l}\text { Możliwa } \\
\text { potrzeba }\end{array}$ & $\begin{array}{c}\text { Potrzeba } \\
\text { konieczna }\end{array}$ \\
\hline \multirow{8}{*}{ Biznesowe } & Branding i komunikacja & $30 \%$ & $34 \%$ & $36 \%$ \\
\hline & Informacje o klientach & $26 \%$ & $42 \%$ & $32 \%$ \\
\hline & Relacje z dostawcami & $43 \%$ & $39 \%$ & $18 \%$ \\
\hline & Modele biznesowe & $35 \%$ & $49 \%$ & $16 \%$ \\
\hline & Ocena łańcucha wartości & $41 \%$ & $44 \%$ & $15 \%$ \\
\hline & Aspekty finansowe & $31 \%$ & $38 \%$ & $31 \%$ \\
\hline & Wartości niematerialne i prawne & $35 \%$ & $41 \%$ & $24 \%$ \\
\hline & Ustawodawstwo & $36 \%$ & $41 \%$ & $23 \%$ \\
\hline \multirow{4}{*}{ Projektowe } & Projekt produktu & $35 \%$ & $33 \%$ & $32 \%$ \\
\hline & Rozwój opakowań & $39 \%$ & $37 \%$ & $24 \%$ \\
\hline & Szacowanie cyklu życia (LCA) & $42 \%$ & $38 \%$ & $20 \%$ \\
\hline & Projekt usługi & $37 \%$ & $44 \%$ & $19 \%$ \\
\hline \multirow{8}{*}{$\begin{array}{l}\text { Technologiczne/ } \\
\text { surowcowe }\end{array}$} & Biokompozyty & $56 \%$ & $31 \%$ & $13 \%$ \\
\hline & Bioresyny & $64 \%$ & $26 \%$ & $10 \%$ \\
\hline & Recykling & $35 \%$ & $38 \%$ & $27 \%$ \\
\hline & Optymalizacja energii & $18 \%$ & $20 \%$ & $62 \%$ \\
\hline & Efektywność materiałowa & $37 \%$ & $35 \%$ & $28 \%$ \\
\hline & Inne alternatywne materiały & $37 \%$ & $35 \%$ & $28 \%$ \\
\hline & Certyfikaty & $28 \%$ & $45 \%$ & $27 \%$ \\
\hline & Druk 3D & $55 \%$ & $29 \%$ & $16 \%$ \\
\hline
\end{tabular}

Źródło: opracowanie własne

jest już postrzegane jako warunek konieczny, stymulujący ekoinnowacyjność i ekoinnowacje. Uzasadniają to potrzeby: brandingu, komunikacji, pozyskania wiedzy o klientach, jak również pozostałe wyróżnione potrzeby biznesowe badanych MSP, m.in. takie jak: wartości niematerialne i prawne, wsparcie legislacyjne.

Badane nadbałtyckie małe i średnie przedsiębiorstwa, określając swoje potrzeby w działalności ekoinnowacyjnej, oczekują również wsparcia w zakresie projektowania ekoinnowacyjnej produkcji, produktów i usług. W szczególności dotyczy to wsparcia zewnętrznego $\mathrm{w}$ procesach projektowania produktów. W grupie badanych MSP aż 33\% przewiduje potrzeby wsparcia w tym zakresie, a $32 \%$ stwierdza, że wsparcie w procesach projektowania ekoinnowacyjnych produktów jest już obecnie konieczne jako stymulanta ich zrównoważonej produkcji. Propozycja ze strony sieci Ecolabnet dotycząca wsparcia w zakresie szacowania cyklu życia ekoinowacyjnych rozwiązań (LCA) jest postrzegana na niższym poziomie. Obecnie tylko $20 \%$ badanych MSP wykazuje taką potrzebę. Są to przedsiębiorstwa, w których ekoinnowacje są w pełni zintegrowane ze strategią firmy lub ich misja opiera się na ekoinnowacjach. Wyróżnienie potrzeb biznesowych i projektowych można traktować jako uzasadnienie, że oczekiwane formy wsparcia nie ograniczają się obecnie w grupie MSP do finansowych i technologicznych.

Niemniej potrzeby technologiczne są również bardzo istotne. Zostały one też zagregowane i podlegały selekcji przez przedsiębiorstwa biorące udział w badaniu. W kontekście ba- dań własnych $62 \%$ badanych podmiotów oczekuje obecnie wsparcia w zakresie optymalizacji zużycia energii. Z kolei $20 \%$ badanych MSP uważa, że oczekiwanie wsparcia w tym w zakresie jest możliwe. Badane nadbałtyckie przedsiębiorstwa oczekują również wsparcia w zakresie recyklingu (możliwa potrzeba - $31 \%$, konieczna potrzeba - 27\%) i wsparcia w procesach poprawy efektywności materiałowej (możliwa potrzeba - 35\%, konieczna potrzeba - 28\%). Natomiast w przypadku technologii i surowców, takich jak: biokompozyty, bioresyny czy druk 3D, obecne potrzeby nadbałtyckich małych i średnich przedsiębiorstw są nieznaczne. Wyróżnione potrzeby zostały wskazane przez przedsiębiorstwa, w których ekoinnowacje wpisują się w ich misję lub/i strategię.

$\mathrm{W}$ odniesieniu do wszystkich potrzeb zagregowanych $\mathrm{w}$ trzech kategoriach: biznesowe, projektowe i technologiczne, stwierdza się, że obecnie potrzeby te i oczekiwane formy wsparcia są silnie zdywersyfikowane, co potwierdzają wyniki badań w grupie nadbałtyckich MSP.

\section{Podsumowanie}

7 uwagi na niski poziom ekoinnowacyjności wielu gospodarek świata niezbędne jest podejmowanie działań mających na celu zwiększenie tego poziomu poprzez nasycenie rozwiązaniami ekoinnowacyjnymi wszystkich procesów biznesowych. Konieczny jest zatem rozwój każdego typu ekoinnowacji, a nie tylko ekoinnowacji produktowych czy procesowych. Działania w tym obszarze podejmują 
liczne ośrodki badawczo-rozwojowe. Jest to również nadrzędnym celem projektu Ecolabnet, realizowanego przez międzynarodowy zespół badaczy.

W artykule zaprezentowano cele i zadania cząstkowe realizowane w projekcie. Podkreślono, że wymierną wartością realizowanej sieci Ecolabnet jest budowanie kompetencji partnerów, organizacji pośredniczących, a przede wszystkim kompetencji ekoinnowacyjnych małych i średnich przedsiębiorstw. Dotyczy to kompetencji w zakresie opracowywania i komercjalizacji zrównoważonych ekoinnowacji poprzez działania edukacyjne, informacyjne i promocyjne. Projekt ma charakter otwarty. Wszystkie małe i średnie przedsiębiorstwa mogą aktywizować swoją działalność ekoinnowacyjną w sieci Ecolabnet, która zapewnia współpracę $\mathrm{z}$ wieloma przedsiębiorstwami, instytucjami biznesowymi, jak również jednostkami naukowo-badawczymi, zlokalizowanymi w krajach regionu Morza Bałtyckiego.

Aby można było wspomagać przedsiębiorstwa w rozwoju ekoinnowacyjności, w szczególności przedsiębiorstwa z sektora MSP, należy najpierw zdiagnozować ich potrzeby i oczekiwania w tym zakresie. Wyniki przeprowadzonych badań wykazały, że potrzeby i oczekiwania są duże i dotyczą różnych aspektów organizacyjnych. Założony cel został osiągnięty.

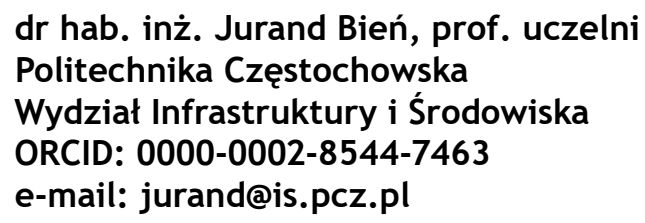

dr hab. inż. Waldemar Jędrzejczyk, prof. uczelni Politechnika Częstochowska

Wydział Zarządzania

ORCID: 0000-0001-7820-8352

e-mail: waldemar.jedrzejczk@wz.pcz.pl

\section{dr hab. inż. Robert Kucęba, prof. uczelni \\ Politechnika Częstochowska \\ Wydział Zarządzania \\ ORCID: 0000-0002-3904-0523 \\ e-mail: robert.kuceba@wz.pcz.pl}

\section{Przypis}

5) Artykuł został opracowany w ramach projektu: „Network of Service Providers for Eco-innovations in Manufacturing SMEs - ECOLABNET" (\#R077), realizowanego w ramach Programu Interreg Regionu Morza Bałtyckiego 2014-2020.

\section{Bibliografia}

[1] Bocken N.M.P., Farracho M., Bosworth R., Kemp R. (2014), The Front-end of Eco-innovation for Eco-innovative Small and Medium Sized Companies, „Journal of Engineering and Technology Management”, Vol. 31, pp. 43-57. DOI: 10.1016/j.jengtecman.2013.10.004.

[2] Burger T. (2005), Green Awareness of Polish Society, Institute of Economy and Urban Area, Warsaw.

[3] Cichy M.J., Szafraniec M. (2015), Ekoinnowacyjność przedsiębiorstw Czystszej Produkcji w Polsce. Część 1. Ogólne aspekty ekoinnowacyjności, Zeszyty Naukowe Politechniki Śląskiej, Seria: Organizacja i Zarządzanie, Nr 77, s. 19-37.

[4] CP, https://www.cp.org.pl/, data dostępu: 9.01.2020 r.

[5] Diabat A., Govindan K. (2011), An Analysis of the Drivers Affecting the Implementation of Green Supply Chain Management, „Resources Conservation and Recycling”, Vol. 55, No. 6, pp. 659-667.

[6] Dudek M., Prandecki K., Wrzaszcz W., Żekało M. (2019), Jak powstaja innowacje ekologiczne $w$ gospodarstwach rolnych? Analiza i przykłady, IERiGŻ-PIB, Warszawa.

[7] EC (2006), Competitiveness and Innovation Framework Programme (2007-2013), European Commission, Brussels.

[8] ECOLABNET, https://ecolabnet.org, access date: 10.01.2020.

[9] EIO (2013), Europe in Transition: Paving the Way to a Green Economy through Eco-innovation, Eco-Innovation Observatory, Funded by the European Commission, DG Environment, Brussels.

[10] GUS (2010), Działalność innowacyjna przedsiębiorstw 2006-2009, GUS, Warszawa.

[11] Karaarslan S. (2015), Eco-innovation Competitiveness Inland shipping, Erasmus University Rotterdam, Rotterdam.

[12] Kaźmierczak-Piwko L., Lewandowska U., Prosół H., Tarnas A. (2017), Innowacje ekologiczne w energetyce jako czynnik konkurencyjności gospodarki, „Systemy Wspomagania w Inżynierii Produkcji”, Vol. 6, Nr 1, s. 96-105.

[13] Kemp R., Pearson P. (2007), Final Report MEI Project about Measuring Eco-innovation, Um-Merit, Maastricht.

[14] Kuceba R. (2019a), Environmental Management and Green Attitudes of the European SME Sector, [in:] A. Hamrol, A. Kujawińska, M. Barraza, M.F. Suarez (eds.), Advances in Manufacturing II. Vol. 2 - Production Engineering and Management, Springer, Cham, pp. 12-25, DOI: 10.1007/9783-030-18789-7_2.

[15] Kuceba R. (2019b), Levels of Pro-Environmental Maturity in Micro and Small Enterprises, „System Safety: Human - Technical Facility - Environment", Vol. 1, No. 1, pp. 256-264, DOI: 10.2478/czoto-2019-0033.

[16] Kuceba R., Zawada M. (2019), The Influence of Environmental Awareness and Attitudes of Entrepreneurs on the Acceleration of co-Innovation in Micro and Small Enterprises, "International Journal of Management and Applied Science”, Vol. 5, No. 9, pp. 67-72.

[17] Łączny J.M., Baran J., Ryszko A. (red.), (2012), Opracowywanie $i$ wdrażanie innowacyjnych technologii środowiskowych stosowanych na zwałowiskach odpadów poweglowych. Podstawy teoretyczno-metodyczne i przykłady praktyczne, Wydawnictwo Naukowe ITEPIB, Radom.

[18] OECD (2005), Oslo Manual 2005: Guidelines for Collecting and Interpreting Innovation, Data, 3rd Edition, OECD, Eurostat.

[19] OECD (2019), Oslo Manual 2018: Guidelines for Collecting, Reporting and Using Data on Innovation, 4th Edition, OECD, Eurostat. 
[20] Rennings K. (2000), Redefining Innovation - Eco-innovation Research and the Contribution from Ecological Economics, „Ecological Economics”, Vol. 32, No. 2, pp. 319-332.

[21] Ryszko A. (2014), Motywacje i bariery działalności ekoinnowacyjnej przedsiębiorstw w Polsce, „Modern Management Review", Vol. 21, No. 1, pp. 127-138.

[22] Triguero A., Moreno-Mondéjar L., Davia M.A. (2013), Drivers of Different Types of Eco-innovation in European SMEs, „Ecological Economics”, Vol. 92, pp. 25-33, DOI: 10.1016/ j.ecolecon.2013.04.009.

[23] WCED (1987), Our Common Future, World Commission on Environment and Development, Oxford University Press, Oxford, New York.

\section{The Eco-innovative Needs of SMEs and the Potential of the Ecolabnet Eco-innovation Network}

\section{Summary}

The article presents the issue of development of eco-innovations, which determine the level of eco-innovativeness not only of individual companies, but also of regions and countries. Due to the low level of eco-innovation in many economies of the world, it is necessary to take measures to increase this level by saturating all business processes with eco-innovative solutions. An example of an initia- tive that aims to stimulate eco-innovative behavior is the Ecolabnet project. The article presents the main research and development tasks in implementation of product eco-innovations and business processes, carried out by an international network of partners (Network of Service Providers for Eco-innovations in Manufacturing SMEs - Ecolabnet) representing research and development units from six Baltic countries. This network was created within the framework of the implemented Baltic Sea Region Interreg Program 2014-2020 - a transnational cooperation program which supports the development of territorial integration in order to increase the eco-innovation, accessibility and sustainable development of the Baltic Sea region countries. In order to support enterprises in the development of eco-innovativeness, in particular SMEs, it is necessary to first diagnose their needs and expectations in this respect. The main objective of the article is to determine the needs and expectations of SMEs in the area of eco-innovation, the knowledge of which will enable the construction of a "tailor-made" repository of knowledge in the Ecolabnet eco-innovation network. The results of the conducted research have shown that the companies' needs and expectations are large and concern various organizational aspects.

\section{Keywords}

eco-innovation, eco-innovativeness, SMEs, Baltic Sea region countries, Ecolabnet project 